\title{
Variation of the Leaf Area Index of Some Vegetables Commonly Grown in Greenhouse Conditions with Cultural Practices
}

\section{Cihan KARACA ${ }^{1}$ D Dursun BÜYÜKTAŞ ${ }^{1}$}

\author{
${ }^{1}$ Akdeniz University Faculty of Agriculture Department of Agricultural Structures and Irrigation, 07058, \\ Antalya / Turkey
}

\author{
Article History \\ Received 26 October 2020 \\ Accepted 23 March 2021 \\ First Online 03 April 2021
}

\section{Corresponding Author}

E-mail: cihankaraca@akdeniz.edu.tr

\author{
Keywords \\ Solanum lycopersicum L. \\ Solanum melongena L. \\ Capsicum annuum L. \\ Cucumis sativus $\mathrm{L}$. \\ Leaf pruning
}

\begin{abstract}
Leaf area index (LAI) values in plants affect photosynthesis and carbohydrate production directly since it is a measure of photosynthetically active area and the area where transpiration occurs. Leaf area index is an important parameter required to determine plant water consumption by using climatic data and it is especially used in the calculation of aerodynamic resistance. Leaf area index varies depending on plant varieties and cultural practices and can be determined directly and indirectly by various methods. In this study, it was aimed to determine the LAl of four different crops (tomato, eggplant, cucumber and pepper) grown in Antalya, where greenhouse cultivation is intensive, depending on the cultural practices. The results showed that LAI was significantly affected by cultural practices such as leaf pruning and climatic differences. Leaf area index obtained from this study can be used to determine the crop evapotranspiration and aerodynamic resistance of four different plants grown under similar conditions.
\end{abstract}

\section{Introduction}

Leaf area index ( $\mathrm{LAI})$ is an important parameter needed in studies such as plant nutrition, competition between plants, soil-water relations, evapotranspiration, photosynthesis, plant protection measures, light reflection and heat transfer in crops (Karaca, 2020). Watson (1947) defined the LAI as the area of one-side green leaf tissue per unit area of land covered by the crop. Leaf area index determines the size of the crop-atmosphere interface, thus it plays a key role in the energy and mass exchange between the plant and the atmosphere (Weiss et al., 2004; Aydinsakir and Buyuktas, 2009). Changes in environmental conditions and differences in cultural practices affect leaf width and height, leaf number, yield and quality (Baudoin et al., 2013). In contrast, the ratio between leaf width and length is not affected by these differences (Rolland-Lagan et al., 2014).

Leaf area index varies according to the vegetation composition, stage of growth and seasons. In addition, it shows a significant variation due to the differences in growing conditions and cultural practices (Zhao et al., 2012). In greenhouse cultivation, cultural practices such as training, removal of new side shoots, shoot apices and leaves, leaf pruning, flower pruning and fruit pruning are made in order to achieve higher yield and quality per unit area (Tuzel, 2013). It is one of the most recommended agricultural practices in order to determine the number of the main stems that plants will continue to grow and to ensure that their development continues on these main branches, to increase yield and to make more use of sunlight for plants (Mendoza-Pérez et al., 2017).

There are various agricultural stereotyped cultural practices in greenhouse cultivation in Antalya. For example, in tomato plants, the leaves under the fruit that are big enough are plucked in order to make the fruit to color flushing faster. This application starts at the root collar of the plant and continues until it reaches the top of the plant. Therefore, very few leaves are left in the plant near 
the removal of the plant (Ildır and Aktaş, 2018). Similar cultural practices are performed in the cucumber. The most important cultural practices affecting the LAI in eggplant and pepper are the number of branches left in the hang of string stage and leaf pruning. Therefore, the LAI varies regionally according to different cultural practices.

Greenhouse cultivation in Antalya are made on an area of 77209 ha. Greenhouse production percentages can be expressed as $60 \%$ for tomato, $14 \%$ for cucumber, $11 \%$ for pepper, $4 \%$ for eggplant and $11 \%$ for others (TUIK, 2020). Due to the high contribution of greenhouse cultivation to the national economy, many academic studies are carried out. Leaf area index is needed especially in experiments related to crop water requirement (Karaca et al., 2018). In the FAO method (ET $\mathrm{F}_{\mathrm{c}}=\mathrm{ET}_{\mathrm{o}}$ $\times \mathrm{k}_{\mathrm{c}}$ ), which is widely used in evapotranspiration estimation, the regional calibration of the plant coefficient $\left(\mathrm{k}_{\mathrm{c}}\right)$ is determined as a function of the LAI (Allen et al., 1998). For this reason, leaf pruning should be considered when determining the LAI. Morever, the $\mathrm{LAl}$ is also needed to determine aerodynamic resistance by dimensionless numbers (Reynolds (Re), Grashof (Gr), Nusselt (Nu), Rayleigh (Ra), Richardson (Ri), Prandtl (Pr), Schmidt (Sc), Sherwood (Sh), and Lewis (Le) (Stanghellini, 1987).

In this study, it was aimed to determine the seasonal variation of $\mathrm{LAI}$ values of vegetables (tomato, eggplant, pepper and cucumber) commonly grown under greenhouse conditions depending on the cultural practices in Antalya region.

\section{Materials and Methods}

This experiment was carried out for two growing seasons under the conditions of a lysimeter in a plastic greenhouse at Akdeniz University $30^{\circ} 38^{\prime} 30 " \mathrm{~N}-30^{\circ} 39^{\prime} 45^{\prime \prime E}$, Antalya-Turkey. The first and second seasons of the experiment were conducted from September 14, 2018 to February 21, 2019 and from March 01, 2019 to July 15, 2019, respectively. Anit F1 tomato, Ayda F1 cucumber, Corsica F1 eggplant and Buket F1 pepper varieties, which are suitable for both autumn and spring cultivation in Antalya Region, were used as plant material. The spacing between the rows, the spacing along the rows of plants and the number of plants in a parcel in the research are given in Table 1. These distances were chosen based on farmer behaviours.

Lysimeter soil had a silty-clay-loam texture (USDA, 1999) and irrigation water was in $\mathrm{C}_{2} \mathrm{~S}_{1}$ (USSL, 1956) class. When $20 \%$ of the available soil moisture in the upper $60 \mathrm{~cm}$ soil profile was consumed, irrigation water was applied to bring the existing moisture to the field capacity. Leaf area (LA) was determined by a non-destructive method based on leaf dimensions (Karaca, 2020). The LAI of a plant canopy is defined as the one-sided green leaf area per unit ground surface area and is calculated as in Equation 1.

$\mathrm{LAI}=(\mathrm{LA} \times \mathrm{n}) / \mathrm{A}$

Where; LAl is the leaf area index $\left(\mathrm{cm}^{2} \mathrm{~cm}^{-2}\right)$; LA is the mean leaf area $\left(\mathrm{cm}^{2}\right) ; n$ is the number of leaves; and $A$ is the area $\left(\mathrm{cm}^{2}\right)$.

All cultural practices were made taking into consideration the behaviour of the farmers. Leaf width (W), length ( $L$ ) and the number of leaves for all plants were measured every 10 days during the growing period. The values on the days when these values were not measured were determined by interpolation method.

In the present study, the tomato was grown on a single central stem supported by a string when it reached $40 \mathrm{~cm}$. The plant was checked regularly and new side shoots were removed from the plant. Furthermore, shoot apices were removed from the plant starting from the $8^{\text {th }}$ fruit. Pepper and eggplant were trained to three main stems. These stems were supported by a string when it reached $40 \mathrm{~cm}$. All leaves, branches and shoots under the selected stems were removed from the plant. The cucumber was cultivated on a single main stem and when it reached $30 \mathrm{~cm}$ in height, it was supported with a string. For better plant growth, all fruits and shoots up to $30 \mathrm{~cm}$ of plant height were removed from the plant. Leaf pruning was performed according to IIdır and Aktaş (2018) in tomato, MEGEP (2008b) in eggplant, MEGEP (2008a) in pepper and MEGEP (2007) in cucumber.

The soil was analyzed before planting for an accurate fertilization program. Fertilization was carried out by fertigation technique, considering the soil analysis and the growth of the plants. Crop water requirement was determined based on soil and irrigation water was given by drip irrigation

Table 1. The spacing between the rows, the spacing along the rows of plants and the number of plants in a lysimeter parcel in the research

\begin{tabular}{lccc}
\hline Crop & $\begin{array}{c}\text { Spacing between } \\
\text { the rows }(\mathrm{cm})\end{array}$ & $\begin{array}{c}\text { Spacing along } \\
\text { the rows }(\mathrm{cm})\end{array}$ & $\begin{array}{c}\text { Number of plants } \\
\text { in a parcel }\left(5 \mathrm{~m}^{2}\right)\end{array}$ \\
\hline Tomato & 50 & 60 & 15 \\
Eggplant & 50 & 100 & 10 \\
Pepper & 50 & 60 & 15 \\
Cucumber & 50 & 60 & 15 \\
\hline
\end{tabular}


system. The experiment was designed according to randomized block design with 3 replications.

\section{Results and Discussion}

Leaf are index for different growing seasons for tomato, eggplant, pepper and cucumber are given in Figures 1, 2, 3 and 4, respectively.

Leaf area index in tomato plants in both growing periods increased approximately until the $90^{\text {th }}$ day after planting (DAP) (Figure 1). In the following days, it was determined that the LAl gradually decreased as a result of leaf pruning, which is one of the most common cultural practices in this region. The LAl of the tomato plant was approximately $1.5 \mathrm{~m}^{2} \mathrm{~m}^{-2}$ at the end of both growing periods while the highest $\mathrm{LAl}$ in the fall and spring periods was 4.1 and $4.3 \mathrm{~m}^{2} \mathrm{~m}^{-2}$, respectively. Harmanto et al. (2005) determined the LAl of cherry tomatoes under stressfree conditions stress-free conditions in greenhouse as $4.0 \mathrm{~m}^{2} \mathrm{~m}^{-2}$, while Al Mamun Hossain et al. (2017) obtained as $4.6 \mathrm{~m}^{2} \mathrm{~m}^{-2}$. Heuvelink et al. (2005) reported that the maximum LAI of tomato grown in the greenhouse was between 3.3 and $4.1 \mathrm{~m}^{2} \mathrm{~m}^{-2}$ and constantly changed during the season as a result of leaf pruning. Similarly, Ambroszczyk et al. (2008) stated that the LAl changed depending on the leaf pruning application.

The LAI of the eggplant plant increased continuously during the fall and spring periods and were determined as 10.9 and $7.7 \mathrm{~m}^{2} \mathrm{~m}^{-2}$ at the end of the growing periods, respectively (Figure 2). Tripathi et al. (2015) reported that the LAl of the eggplant irrigated with wastewater increased continuously until the $100^{\text {th }}$-day DAP and reached $4.2 \mathrm{~m}^{2} \mathrm{~m}^{-2}$, and then the crops did not grow. Yıldırım (2015) found that the LAl of the eggplant reached the highest level $\left(2.8 \mathrm{~m}^{2} \mathrm{~m}^{-2}\right)$ on the $88^{\text {th }}$ of DAP under field conditions in a similar climate and it decreased continuously until the $113^{\text {th }}$ of DAP $\left(2.0 \mathrm{~m}^{2} \mathrm{~m}^{-2}\right)$, which was the end of the growing season. Karam et al. (2011) announced that the maximum LAl of the eggplant varied approximately between 6.0 and $7.0 \mathrm{~m}^{2} \mathrm{~m}^{-2}$ during the two growing seasons and the LAl was constantly decreasing near the plant removal. Contrary to the studies in the literature, LAl of the eggplant showed an increasing trend in our study. Passioura and Angus (2010) declared that when vegetables were exposed to water stress, their life cycles shortened and physiological aging accelerated. Besides, since eggplant is a perennial plant, if the plant does not encounter stress, it continues to grow continuously. Therefore, a higher LAI was obtained in the fall period, when the growing period was longer than the spring period.

Similar to the eggplant, the LAl of the pepper increased continuously throughout the growing periods and reached $3.2 \mathrm{~m}^{2} \mathrm{~m}^{-2}$ in the fall period and $3.9 \mathrm{~m}^{2} \mathrm{~m}^{-2}$ in the spring period (Figure 3). Ta et al. (2011) reported that the LAI of pepper in the rock wool growing environment in the glasshouse increased continuously from seedling to plant removal and reached approximately $3.0 \mathrm{~m}^{2} \mathrm{~m}^{-2}$. Moreno et al. (2003) obtained the highest LAI $\left(3.5 \mathrm{~m}^{2} \mathrm{~m}^{-2}\right)$ from full irrigation in the study that different irrigation levels were applied in field conditions. On the other hand, Mendoza-Pérez et al. (2017) found that the number of the main stem in the plant also affected the LAI and the highest LAI $\left(2.8 \mathrm{~m}^{2} \mathrm{~m}^{-2}\right)$ was obtained from the plants growing on more than two main stems. Rubio et al. (2011) obtained the highest LAI $\left(3.2 \mathrm{~m}^{2} \mathrm{~m}^{-2}\right)$ of the pepper plant grown in different nutrient solutions at different salinity levels and depending on the number of main stems from the plant growing on three main stems. In the present study, the pepper plant was cultivated to be grown on three main stems, and the results obtained are consistent with the literature.

When the LAI of the cucumber in both growing seasons was examined, the LAl increased to $3.9 \mathrm{~m}^{2} \mathrm{~m}^{-2}$ until the $90^{\text {th }}$ of DAP in the fall season, and $7.5 \mathrm{~m}^{2} \mathrm{~m}^{-2}$ until the $120^{\text {th }}$ of DAP in the spring season (Figure 4). The differences in the fall and spring seasons were due to the greenhouse conditions and the cultural practices applied to the plant. In the region, leaf pruning in the fall period is more common than in the spring period. The most important reason for this is to protect the plant from fungal diseases caused by increased humidity and to create an airy root zone. Morever, the humidity inside the greenhouse increased significantly due to the closing of the roof ventilation on rainy days. In order to prevent this excessive moisture inside the greenhouse from damaging the plants, more leaf pruning was done in the fall seasons compared to the spring season. As a result, the LAI in the fall season was less than in the spring season. Al Mamun Hossain et al. (2017) stated that the maximum LAl of cucumber grown under conditions without stress was $3.0 \mathrm{~m}^{2} \mathrm{~m}^{-2}$ during the 70 -day growing period. Nederhoff et al. (1988) announced that the LAI oscillated during the season and the maximum LAI was $3.5 \mathrm{~m}^{2} \mathrm{~m}^{-2}$. Similarly, in our study, it was determined that the LAl of cucumber went up and down in the fall season, while the maximum LAl was $3.9 \mathrm{~m}^{2} \mathrm{~m}^{-2}$. There are important differences between the LAl determined in the spring period and the LAl found in the literature. These differences were thought to occur due to the greenhouse conditions and the length of the growing period.

YIldIZ (2018) determined the LAI of greenhouse plants in the Mediterranean region based on the plant growth stages [beginning (1), development (2), middle (3) and last (4) periods] using the method by Allen et al. (1998). The researcher reported that the LAl in the $3^{\text {rd }}$ and $4^{\text {th }}$ growth stages of the fall period was 3.2 and $2.9 \mathrm{~m}^{2} \mathrm{~m}^{-2}$ in tomato and 3.3 and $3.0 \mathrm{~m}^{2} \mathrm{~m}^{-2}$ in cucumber, respectively. In the spring season, the LAI of the crops in the $3^{\text {rd }}$ and $4^{\text {th }}$ development stages were 3.5 and $3.3 \mathrm{~m}^{2} \mathrm{~m}$ 2 in tomato; 3.2 and $3.0 \mathrm{~m}^{2} \mathrm{~m}^{-2}$ in eggplant; 3.1 and 

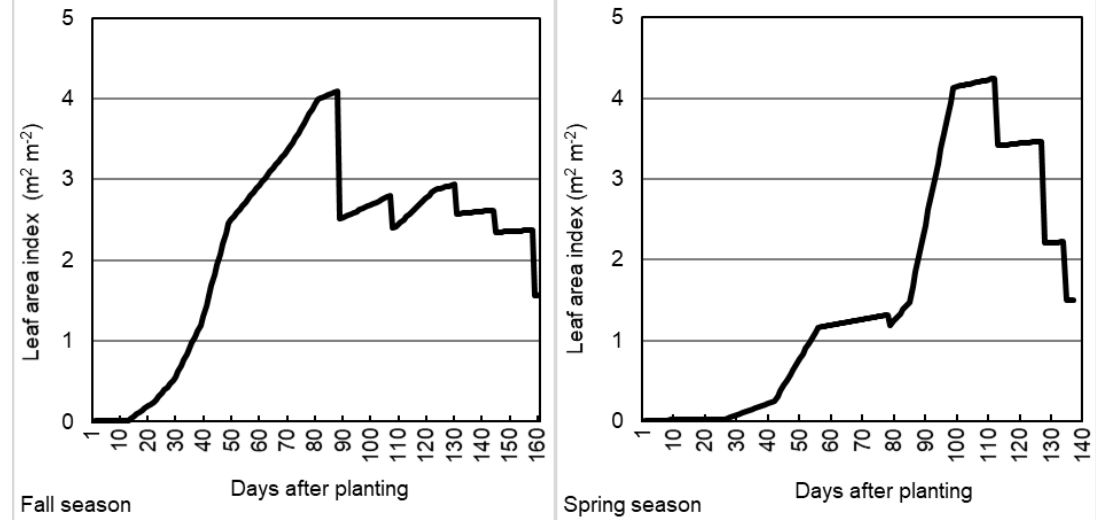

Figure 1. Seasonal change in leaf area index (LAl) for tomato
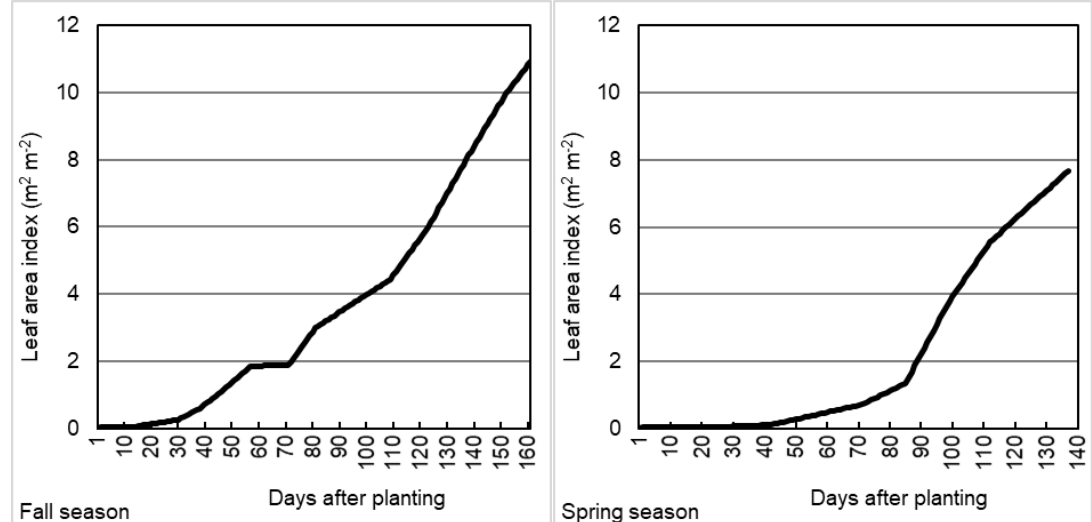

Figure 2. Seasonal change in leaf area index (LAI) for eggplant
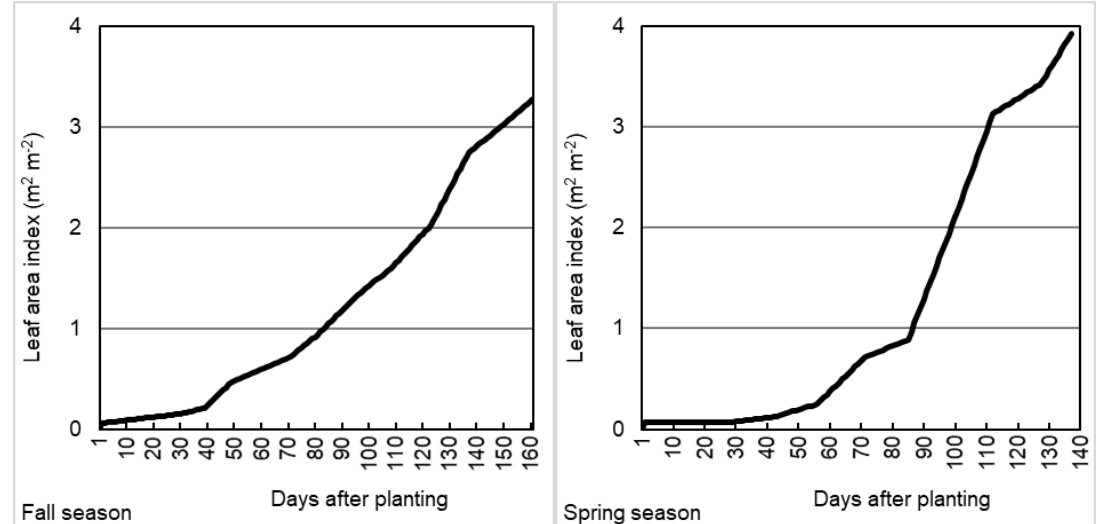

Figure 3. Seasonal change in leaf area index (LAl) for pepper
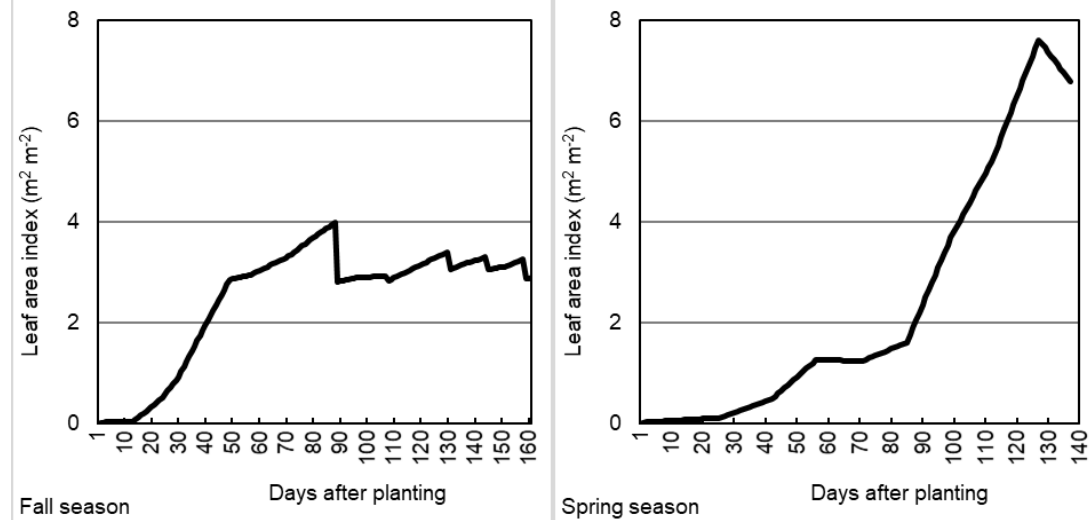

Figure 4. Seasonal change in leaf area index (LAI) for cucumber 
$3.0 \mathrm{~m}^{2} \mathrm{~m}^{-2}$ in pepper; 3.6 and $3.4 \mathrm{~m}^{2} \mathrm{~m}^{-2}$ in cucumber, respectively. When the LAI was examined, there were differences between our study and Yıldız (2018). One of the most important reasons for these differences was that Yıldız (2018) determined the LAl by assuming no leaf pruning practice. However, leaf pruning practice is widely carried out by the growers in the region. In addition, while in our study, models derived specifically for the region and plant varieties were used to determine the LA, Yıldız (2018) used models previously developed for other regions. Differences in the LAl occurred due to these reasons.

If we evaluate the seasonal changes of the LAI of all plants, in general, it was determined that the plant growth right after the planting seedlings at the beginning of the spring season was slower compared to the fall season. The reason for this was the low temperature in this period and the lower incoming solar energy compared to the other season. In addition, the highest LAl in all crops was observed in the spring season due to the suitable climate conditions. When the results obtained from this study and all the studies mentioned above were evaluated in general, it was determined that the LAI of the plants was affected by the greenhouse conditions and various cultural practices.

\section{Conclusion}

In this study, seasonal variation of the LAI of some vegetables commonly grown under greenhouse conditions were investigated. It was determined that the LAI was affected by cultural practices. Since leaf pruning is a common practice in greenhouse growing under Mediterranean conditions, this cultural practice should be taken into account in the methods developed to calculate the change of LAI. Otherwise, methods based on the LAI to calculate the crop coefficient will not be calculated correctly and therefore the crop evapotranspiration will be estimated incorrectly. Leaf area index obtained from this study can be used confidently in determining evapotranspiration and aerodynamic resistance under similar conditions.

\section{Acknowledgements}

This study was supported by Akdeniz University Research Funds, Grant No: FDK-2018-2966. Plant material in this research was obtained from TOVAG: 1170071 numbered project-Scientific and the Technological Research Council of Turkey (TUBITAK).

\section{References}

Al Mamun Hossain, S.A., Wang, L., Chen, T., \& Li, Z. (2017). Leaf area index assessment for tomato and cucumber growing period under different water treatments. Plant, Soil and Environment, 63:461-467.
Allen, R.G., Pereira, L.S., Raes, D., \& Smith, M. (1998). Crop evapotranspiration: Guidelines for computing crop water requirements. FAO Irrigation and Drainage Paper 56. Rome, Italy.

Ambroszczyk, A.M., Cebula, S., \& Sekara, A. (2008). The effect of plant pruning on the light conditions and vegetative development of eggplant (Solanum melongena L.) in greenhouse cultivation. Vegetable Crops Research Bulletin, 68:57-70.

Aydinsakir, K., \& Buyuktas, D. (2009). Non-destructive leaf area estimation in carnation plants. Akdeniz University Jounal of Agriculture Faculty, 22:83-89.

Baudoin, W., Nono-Womdim, R., Lutaladio, N., Hodder, A., Castilla, N., Leonardi, C., Pascale, S. De, \& Qaryouti, M. (2013). Good Agricultural Practices for greenhouse vegetable crops-Principles for Meditterranean climate areas. Food and Agriculture Organization of the United Nations. Rome, Italy.

Harmanto, Salokhe, V.M., Babel, M.S., \& Tantau, H.J. (2005). Water requirement of drip irrigated tomatoes grown in greenhouse in tropical environment. Agricultural Water Management, 71:225-242.

Heuvelink, E., Bakker, M.J., Elings, A., Kaarsemaker, R., \& Marcelis, L.F.M. (2005). Effect of leaf area on tomato yield. Acta Horticulturae, 691:43-50.

Ildır, M.İ., \& Aktaş, H. (2018). Effect of different type of pruning on the yield and quality of greenhouse tomato production. Süleyman Demirel University Journal of Natural and Applied Sciences, 22:1241-1248.

Karaca, C., Tezcan, A., Buyuktas, K., Buyuktas, D., \& Bastug, R. (2018). Equations developed to estimate evapotranspiration in greenhouses. Yuzuncu $Y_{l}$ University Journal of Agricultural Sciences, 28:482489.

Karaca, C. (2020). Evapotranspiration of crops widely grown in greenhouses using the energy balance method. PhD Thesis, Akdeniz University, Antalya.

Karam, F., Saliba, R., Skaf, S., Breidy, J., Rouphael, Y., \& Balendonck, J. (2011). Yield and water use of eggplants (Solanum melongena L.) under full and deficit irrigation regimes. Agricultural Water Management, 98:1307-1316.

MEGEP (2007). Growing of cucumber. Mesleki Eğitim ve Öğretim Sisteminin Güçlendirilmesi Projesi. p. 50. (in Turkish).

MEGEP (2008a). Growing of Pepper. Mesleki Eğitim ve Öğretim Sisteminin Güçlendirilmesi Projesi. p.47. (in Turkish).

MEGEP (2008b). Growing of eggplant Mesleki Eğitim ve Öğretim Sisteminin Güçlendirilmesi Projesi p.35. (in Turkish).

Mendoza-Pérez, C., Ramírez-Ayala, C., OjedaBustamante, W., \& Flores-Magdaleno, H. (2017). Estimation of leaf area index and yield of greenhousegrown poblano pepper. Ingeniería Agrícola $y$ Biosistemas, 9:37-50.

Moreno, M.M., Ribas, F., Moreno, A., \& Cabello, M.J. (2003). Physiological response of a pepper (Capsicum annuum L.) crop to different trickle irrigation rates. Spanish Journal of Agricultural Research, 1:65-74.

Nederhoff, E.M., Gijzen, J.G., \& Vegter, J. (1988). Measurement and simulation of crop photosynthesis of cucumber (Cucumis sativus L.) in greenhouses. Netherlands Journal of Agricultural Science, 36:253264.

Passioura, J. B., \& Angus, J. F. (2010). Improving Productivity of Crops in Water-Limited Environments. In J. B. Passioura, J. F. Angus, \& D. L. Sparks (Eds.), 
Advances in Agronomy. Academic Press, Burlington. pp.37-75.

Rolland-Lagan, A.G., Remmler, L., \& Girard-Bock, C. (2014). Quantifying shape changes and tissue deformation in leaf development. Plant Physiology, 165:496-505.

Rubio, J.S., Pereira, W.E., Garcia-Sanchez, F., Murillo, L., García, A.L., \& Martínez, V. (2011). Sweet pepper production in substrate in response to salinity, nutrient solution management and training system. Horticultura Brasileira, 29:275-281.

Stanghellini, C. (1987). Transpiration of greenhouse crops an aid to climate management. PhD thesis Institute of Agricultural Engineering. Wageningen University, p.150.

Ta, T.H., Shin, J.H., Ahn, T.I., \& Son, J.E. (2011). Modeling of transpiration of paprika (Capsicum annuum L.) plants based on radiation and leaf area index in soilless culture. Horticulture Environment and Biotechnology, 52:265-269.

Tripathi, V.K., Rajput, T.B.S., Patel, N., \& Kumar, P. (2015). Biometric response of eggplant under sustainable micro irrigation with municipal wastewater. In M. R. Goyal (Ed.), Sustainable Practices in Surface and Subsurface Micro Irrigation. Apple Academic Press, pp. 319-331.

TUIK. (2020). Crop Production Statistics-Agricultural Production Areas. http://tuik.gov.tr/PreTablo.do?alt. Date accessed: February 06, 2020.

Tuzel, Y. (2013). Cultural practices. In W. Baudoin, R. Nono-Womdim, N. Lutaladio, \& A. Hodder (Eds.), Good Agricultural Practices for greenhouse vegetable crops - Principles for Meditterranean climate areas. Food and Agriculture Organization of the United Nations, Rome, pp. 379-397.

USDA (1999). Soil taxonomy: A basic system of soil classification for making and interpreting soil surveys (Second Ed.). Natural Resources Conservation Service. U.S. Department of Agriculture Handbook p. 436.

USSL (1956). Diagnosis and improvement of saline and alkali soils. U.S. Dept. Agric. Handbook No.60.

Watson, D.J. (1947). Comparative Physiological Studies on the Growth of Field Crops: I. Variation in Net Assimilation Rate and Leaf Area between Species and Varieties, and within and between Years. Annals of Botany, 11:41-76.

Weiss, M., Baret, F., Smith, G.J., Jonckheere, I., \& Coppin, P. (2004). Review of methods for in situ leaf area index (LAI) determination Part II. Estimation of $\mathrm{LAl}$, errors and sampling. Agricultural and Forest Meteorology, 121:37-53.

Yıldırım, M. (2015). Water and radiation use efficiency of eggplant under none water stress condition in semiarid region. COMU Journal of Agriculture Faculty, 3:71-77.

Yıldız, Ö. (2018). Calculation of crop water requirement for crops grown in greenhouses in the western mediterranean basin. MSc Thesis, Ankara University, Ankara.

Zhao, D., Xie, D., Zhou, H., Jiang, H., \& An, S. (2012). Estimation of Leaf Area Index and Plant Area Index of a Submerged Macrophyte Canopy Using Digital Photography. PLOS ONE, 7:e51034. 